\title{
PATTERNS OF DISTURBED LUNG FUNCTION IN PATIENTS WITH EMPHYSEMATOUS BULLAE
}

\author{
BY \\ COLIN OGILVIE AND MARY CATTERALL \\ From the London Hospital
}

(RECEIVED FOR PUBLICATION AUGUST 15, 1958)

In a previous publication (Ogilvie, 1959) an account was given of the functional disturbance in emphysematous patients without radiologically visible bullae. The purpose of this second paper is to describe the patterns of pulmonary dysfunction in 14 patients with pulmonary bullae and to compare these with the patterns observed in emphysematous patients without bullae. These patients were unselected in that they represented 14 consecutive referrals to the pulmonary function laboratory at the London Hospital. The methods used for measurement of lung function were those described previously (Ogilvie, 1959).

Baldwin, Harden, Greene, Cournand, and Richards (1950) described 16 patients with large pulmonary air cysts or bullae and divided them into three groups according to the disturbance in pulmonary function. This classification was based upon the freedom of communication between the large cyst and the bronchial tree and the functional state of the remainder of the lungs. In 14 of these 16 patients, the large cysts or bullae occupied at least the whole of one hemithorax. The authors themselves observed that it may be impossible to judge whether ventilatory insufficiency is due to mechanical interference from a tension cyst or to severe generalized changes in the lungs. In the present series of 14 patients with pulmonary bullae, large bullae occupied more than one-third of the hemithorax in only two, and in two others there were diffuse "honeycomb" changes without large bullae. In five patients, pulmonary function studies were repeated after the larger bullae had been removed. It was therefore hoped that, by studying patients in whom considerable volumes of pulmonary tissue were not compressed or destroyed by giant tension cysts, more exact information might be obtained regarding the functional disturbance in the lungs as a whole.

\section{RESULTS}

The 14 patients with pulmonary bullae have been divided into four subgroups on the basis of clinical and radiological findings. The clinical, radiological, and physiological data are recorded in Tables I-III.

Group $\mathrm{A}$ includes five patients between the ages of 37 and 56. The average age at the time the bullae were first discovered was 35 years. Three had first presented with spontaneous pneumothorax and in the other two bullae had been found in a routine radiograph. They all complained of only slight dyspnoea which was not progressive, although four of them were known to have had bullae in the lung for more than seven years. Bronchitis was not conspicuous: three of the patients were free of cough while the other two only complained of a slight cough for two or three weeks each winter. Three of the five patients gave a history of pneumonia in childhood. In each case the chest radiograph (Fig. 2) revealed one or more large bullae in the upper part of the right lung occupying from one-quarter to two-thirds of the hemithorax. In the oldest patient (No. 24) the radiograph also showed many smaller bullae in both lungs. A bronchogram in one patient showed no abnormality apart from some displacement of the bronchial tree by the bullae.

Pulmonary function studies showed that in this group the bellows action of the lungs was only slightly impaired. The mean vital capacity was $93 \%$ of predicted normal and the mean maximum voluntary ventilation at 80 respirations per minute (M.V.V.80) 84\%. This slight impairment of bellows action was due to a reduction in the maximum inspiratory and expiratory flow rates equally. The diffusing capacity was normal in one patient and moderately reduced in two. The most characteristic abnormality was the increase 
in functional residual capacity (mean: 177\% predicted normal) and residual volume (mean: $233 \%$ predicted normal) in the absence of any significant degree of expiratory bronchial obstruction as measured by the maximum expiratory flow rate (Fig. 1). The ratio of residual volume to total lung capacity was also increased in every case despite the fact that the vital capacity was within the normal range.

The larger bullae were removed from four of these five patients (Nos. 20-23). At thoracotomy, the bullae were found to arise from the right upper lobe and many smaller bullae were visible over the surface of the lung, especially in the upper lobes. The macroscopic and microscopic appearances were compatible with emphysematous bullae: none showed any epithelial lining. In patient No. 21, a left upper lobectomy was performed at a later date for bronchial carcinoma. The resected specimen also showed emphysematous changes. Pulmonary function studies were repeated between three and five

TABLE I

CLINICAL DATA ON 14 PATIENTS WITH EMPHYSEMATOUS BULLAE

\begin{tabular}{|c|c|c|c|c|c|c|c|c|c|}
\hline Group & Patient & $\begin{array}{l}\text { Age } \\
\text { (yr.) }\end{array}$ & $\begin{array}{c}\text { Height } \\
\text { (in.) }\end{array}$ & $\begin{array}{l}\text { Weight } \\
\text { (lb.) }\end{array}$ & $\begin{array}{l}\text { Body } \\
\text { Surface } \\
\text { Area } \\
\text { in } \\
\text { m. }^{\mathbf{2}}\end{array}$ & $\begin{array}{c}\text { Known } \\
\text { Duration } \\
\text { of } \\
\text { Disease } \\
\text { (years) }\end{array}$ & Main Features in History & $\begin{array}{c}\text { Degree } \\
\text { of } \\
\text { Disability }\end{array}$ & $\begin{array}{l}\text { Radiographic } \\
\text { and Surgical Findings }\end{array}$ \\
\hline \multirow[t]{5}{*}{$\mathbf{A}$} & 20 & 37 & 69 & 126 & $1 \cdot 71$ & 2 & Exertional dyspnoea & + & $\begin{array}{l}\text { Air cyst at right apex occupying } \\
\text { quarter hemithorax. Broncho- } \\
\text { gram shows displaced upper lobe } \\
\text { bronchi only. Multiple smaller } \\
\text { subpleural bullae, mainly over } \\
\text { upper lobe }\end{array}$ \\
\hline & 21 & 45 & 72 & 146 & 1.86 & 23 & $\begin{array}{l}\text { Spontaneous pneumothorax } \\
\text { twice, recent exertional dys- } \\
\text { pnoea, mild winter bronchitis }\end{array}$ & ++ & $\begin{array}{l}\text { Two air cysts at right apex, occupy- } \\
\text { ing half the hemithorax. Smaller } \\
\text { cysts at left apex. Multiple } \\
\text { subpleural bullae, mainly over }\end{array}$ \\
\hline & 22 & 42 & 70 & 135 & $1 \cdot 78$ & 7 & $\begin{array}{l}\text { M.M.R. finding, mild winter } \\
\text { bronchitis and exertional dys- } \\
\text { pnoea }\end{array}$ & + & $\begin{array}{l}\text { Air cyst occupying upper two-thirds } \\
\text { of right hemithorax. Multiple } \\
\text { subpleural bullae, mainly over } \\
\text { upper lobe }\end{array}$ \\
\hline & 23 & 48 & 69 & 144 & $1 \cdot 80$ & 10 & Spontaneous pneumothorax & - & $\begin{array}{l}\text { Two air cysts with fluid levels } \\
\text { occupying upper third of right } \\
\text { hemithorax. Multiple subpleural } \\
\text { bullae }\end{array}$ \\
\hline & 24 & 56 & 70 & 170 & 1.94 & 10 & $\begin{array}{l}\text { Spontaneous pneumothorax, } \\
\text { slight exertional dyspnoea }\end{array}$ & + & $\begin{array}{l}\text { Air cyst occupying upper quarter of } \\
\text { right hemithorax. Increased } \\
\text { markings both lungs suggestive } \\
\text { of generalized bullous changes }\end{array}$ \\
\hline \multirow[t]{2}{*}{ B } & 25 & 21 & 69 & 147 & 1.82 & (None) & $\begin{array}{l}\text { Routine M.M.R. finding, no } \\
\text { symptoms }\end{array}$ & - & $\begin{array}{l}\text { Air cyst occupying lower third of } \\
\text { right hemithorax. Remainder of } \\
\text { lung surface healthy }\end{array}$ \\
\hline & 26 & 30 & 72 & 189 & $2 \cdot 08$ & " & $\begin{array}{l}\text { Routine M.M.R. finding, no } \\
\text { symptoms }\end{array}$ & - & $\begin{array}{l}\text { Air cyst occupying lower third of } \\
\text { left hemithorax. Cyst found to } \\
\text { arise from a sequestrated lobe; } \\
\text { remainder of lung surface healthy }\end{array}$ \\
\hline \multirow[t]{5}{*}{ C } & 27 & 59 & 71 & 145 & 1.83 & 10 & $\begin{array}{l}\text { Winter bronchitis, increasing } \\
\text { exertional dyspnoea }\end{array}$ & ++ & $\begin{array}{l}\text { Air cyst occupying lower third of } \\
\text { right hemithorax. Flattened } \\
\text { diaphragm }\end{array}$ \\
\hline & 28 & 47 & 66 & 148 & $1 \cdot 76$ & 15 & " $\quad "$ & +++ & $\begin{array}{l}\text { Air cyst occupying lower third of } \\
\text { left hemithorax. Probably } \\
\text { smaller cysts at right base also. } \\
\text { Flattened diaphragms }\end{array}$ \\
\hline & 29 & 30 & 68 & 93 & 1.48 & 25 & $\begin{array}{l}\text { Asthma since infancy, persistent } \\
\text { bronchitis and increasing exer- } \\
\text { tional dyspnoea, four episodes } \\
\text { of right heart failure in } 5 \text { years }\end{array}$ & +++ & $\begin{array}{l}\text { Air cyst occupying the lower third } \\
\text { of right hemithorax with smaller } \\
\text { cysts elsewhere. Flattened dia- } \\
\text { phragms. Enlarged pulmonary }\end{array}$ \\
\hline & 30 & 46 & 63 & 85 & $1 \cdot 34$ & 7 & $\begin{array}{l}\text { Occasional winter bronchitis, } \\
\text { exertional dyspnoea }\end{array}$ & + & $\begin{array}{l}\text { Air cyst occupying the lower half } \\
\text { of left hemithorax }\end{array}$ \\
\hline & 31 & 64 & 67 & 94 & 1.48 & 5 & $\begin{array}{l}\text { Winter bronchitis, increasing } \\
\text { exertional dyspnoea, one epi- } \\
\text { sode of right heart failure and } \\
\text { one of pneumonia }\end{array}$ & ++++ & $\begin{array}{l}\text { Air cyst occupying lower half of } \\
\text { right hemithorax. Flattened } \\
\text { diaphragms. Enlarged pulmonary } \\
\text { artery }\end{array}$ \\
\hline \multirow[t]{2}{*}{ D } & 32 & 58 & 69 & 121 & 1.67 & 1 & $\begin{array}{l}\text { Rapidly increasing exertional } \\
\text { dyspnoea, recent cough and } \\
\text { haemoptysis, no preceding } \\
\text { bronchitis }\end{array}$ & $+t+$ & $\begin{array}{l}\text { Small cavitating tuberculous lesion } \\
\text { at left upper zone. Multiple air } \\
\text { cysts (each about } 1 \mathrm{~cm} \text {. diameter) } \\
\text { throughout both lungs. No giant } \\
\text { cysts }\end{array}$ \\
\hline & 33 & 61 & 68 & 168 & 1.9 & 3 & $\begin{array}{l}\text { Cough, wheezing, and increasing } \\
\text { exertional dyspnoea dating } \\
\text { from exposure to smog }\end{array}$ & ++ & $\begin{array}{l}\text { Diffuse cystic changes in both } \\
\text { lungs; no giant cysts }\end{array}$ \\
\hline
\end{tabular}


TABLE II

LUNG VOLUMES AND SUBDIVISIONS IN 14 PATIENTS WITH EMPHYSEMATOUS BULLAE

\begin{tabular}{|c|c|c|c|c|c|c|c|c|c|c|c|}
\hline Group & $\begin{array}{l}\text { Patient } \\
\text { No. }\end{array}$ & $\begin{array}{c}\text { Minute } \\
\text { Volume } \\
\text { (ml.) }\end{array}$ & $\underset{\text { (ml.) }}{\text { Vital }}$ & $\begin{array}{c}\text { V.C. as } \% \\
\text { Normal }\end{array}$ & $\begin{array}{c}\text { Functional } \\
\text { Residual } \\
\text { Capacity } \\
\text { (ml.) }\end{array}$ & $\begin{array}{l}\text { F.R.C. as } \\
\% \text { Normal }\end{array}$ & $\begin{array}{c}\text { Residual } \\
\text { Volume } \\
\text { (ml.) }\end{array}$ & $\begin{array}{l}\text { R.V. as } \% \\
\text { Normal }\end{array}$ & $\begin{array}{c}\text { Total } \\
\text { Lung } \\
\text { Capacity } \\
\text { (ml.) }\end{array}$ & $\begin{array}{l}\text { T.L.C. as } \\
\% \text { Normal }\end{array}$ & $\begin{array}{c}\text { R.V. } \\
\text { T.L.C. } \\
\text { Ratio } \\
(\%)\end{array}$ \\
\hline \multirow[t]{2}{*}{ A } & $\begin{array}{l}20 \\
21 \\
22 \\
23 \\
24\end{array}$ & $\begin{array}{r}7,800 \\
11,700 \\
9,130 \\
9,600 \\
7,552\end{array}$ & $\begin{array}{l}4,470 \\
3,515 \\
4,000 \\
3,625 \\
3,190\end{array}$ & $\begin{array}{r}109 \\
80 \\
98 \\
93 \\
84\end{array}$ & $\begin{array}{l}4,886 \\
6,020 \\
5,270 \\
3,305 \\
4,110\end{array}$ & $\begin{array}{l}189 \\
218 \\
204 \\
135 \\
140\end{array}$ & $\begin{array}{l}3,140 \\
4,325 \\
3,270 \\
2,055 \\
2,660\end{array}$ & $\begin{array}{l}251 \\
323 \\
262 \\
173 \\
156\end{array}$ & $\begin{array}{l}7,610 \\
7,840 \\
7,270 \\
5,680 \\
5,850\end{array}$ & $\begin{array}{l}142 \\
137 \\
136 \\
112 \\
106\end{array}$ & $\begin{array}{l}41 \\
55 \\
45 \\
36 \\
45\end{array}$ \\
\hline & Mean & 9,156 & 3,760 & 93 & 4,718 & 177 & 3,090 & 233 & 6,850 & 127 & 44 \\
\hline \multirow[t]{2}{*}{ B } & $\begin{array}{l}25 \\
26\end{array}$ & $\begin{array}{l}6,390 \\
8,510\end{array}$ & $\begin{array}{l}4,460 \\
5,125\end{array}$ & $\begin{array}{l}101 \\
115\end{array}$ & $\begin{array}{l}2,847 \\
2,740\end{array}$ & $\begin{array}{l}112 \\
107\end{array}$ & $\begin{array}{l}1,487 \\
1,315\end{array}$ & $\begin{array}{l}134 \\
118\end{array}$ & $\begin{array}{l}5,947 \\
6,440\end{array}$ & $\begin{array}{l}108 \\
115\end{array}$ & $\begin{array}{l}25 \\
20\end{array}$ \\
\hline & Mean & 7,400 & 4,793 & 108 & 2,794 & 110 & 1,401 & 126 & 6,194 & 112 & 23 \\
\hline \multirow[t]{2}{*}{ C } & $\begin{array}{l}27 \\
28 \\
29 \\
30 \\
31\end{array}$ & $\begin{array}{l}8,550 \\
8,235 \\
6,916 \\
7,868 \\
7,560\end{array}$ & $\begin{array}{l}3,195 \\
3,165 \\
2,430 \\
1,410 \\
1,420\end{array}$ & $\begin{array}{l}84 \\
85 \\
58 \\
41 \\
52\end{array}$ & $\begin{array}{l}4,270 \\
3,915 \\
3,810 \\
3,550 \\
3,870\end{array}$ & $\begin{array}{l}146 \\
136 \\
160 \\
133 \\
188\end{array}$ & $\begin{array}{l}3,245 \\
3,430 \\
2,610 \\
3,000 \\
3,450\end{array}$ & $\begin{array}{l}192 \\
207 \\
251 \\
198 \\
298\end{array}$ & $\begin{array}{l}6,440 \\
6,110 \\
5,040 \\
4,410 \\
4,870\end{array}$ & $\begin{array}{r}117 \\
112 \\
96 \\
88 \\
125\end{array}$ & $\begin{array}{l}50 \\
56 \\
52 \\
68 \\
71\end{array}$ \\
\hline & Mean & 7,846 & 2,324 & 64 & 3,884 & 153 & 3,147 & 229 & 5,374 & 108 & 59 \\
\hline \multirow[t]{2}{*}{ D } & $\begin{array}{l}32 \\
33\end{array}$ & $\begin{array}{l}22,500 \\
15,000\end{array}$ & $\begin{array}{l}4,150 \\
3,220\end{array}$ & $\begin{array}{r}112 \\
88\end{array}$ & $\begin{array}{l}4,500 \\
4,970\end{array}$ & $\begin{array}{l}158 \\
177\end{array}$ & $\begin{array}{l}3,000 \\
3,970\end{array}$ & $\begin{array}{l}183 \\
245\end{array}$ & $\begin{array}{l}7,150 \\
7,190\end{array}$ & $\begin{array}{l}134 \\
137\end{array}$ & $\begin{array}{l}42 \\
55\end{array}$ \\
\hline & Mean & 18,750 & 3,685 & 100 & 4,735 & 168 & 3,485 & 214 & 7,170 & 136 & 49 \\
\hline
\end{tabular}

TABLE III

VENTILATORY FUNCTION, MIXING EFFICIENCY, AND CARBON MONOXIDE DIFFUSING CAPACITY IN 14 PATIENTS WITH EMPHYSEMATOUS BULLAE

\begin{tabular}{|c|c|c|c|c|c|c|c|c|c|}
\hline Group & $\begin{array}{c}\text { Patient } \\
\text { No. }\end{array}$ & $\begin{array}{c}\text { Maximum } \\
\text { Voluntary } \\
\text { Ventilation } \\
\text { (at } \\
80 \text { resp. } \\
\text { min.) }\end{array}$ & $\mid \begin{array}{c}\text { M.V.V.80 } \\
\text { as \% Normal }\end{array}$ & \begin{tabular}{|c|} 
Increase in \\
M.V.V.80 \\
after \\
Isoprenaline \\
(as \% of \\
Original Value)
\end{tabular} & $\begin{array}{c}\text { Maximum } \\
\text { Inspiratory } \\
\text { Flow Rate } \\
\text { (l. } / \text { min.) }\end{array}$ & $\begin{array}{c}\text { Maximum } \\
\text { Expiratory } \\
\text { Flow Rate } \\
\text { (1. min.) }\end{array}$ & $\begin{array}{c}\text { Alveolar } \\
\text { Mixing } \\
\text { Efficiency } \\
(\%)\end{array}$ & $\begin{array}{l}\text { Diffusing } \\
\text { Capacity } \\
\text { (in } \\
\mathrm{ml} \text {. mm. } \\
\mathrm{Hg} \text { min.) } \\
\text { for } \mathrm{CO}\end{array}$ & $\begin{array}{c}\text { Diffusing } \\
\text { Capacity } \\
\text { as \% } \\
\text { Normal }\end{array}$ \\
\hline \multirow[t]{2}{*}{ A } & $\begin{array}{l}20 \\
21 \\
22 \\
23 \\
24\end{array}$ & $\begin{array}{r}124 \\
74 \\
128 \\
96 \\
62\end{array}$ & $\begin{array}{r}108 \\
62 \\
111 \\
87 \\
55\end{array}$ & $\begin{array}{r}3 \\
24 \\
6 \\
29 \\
26\end{array}$ & $\begin{array}{l}222 \\
214 \\
333 \\
300 \\
200\end{array}$ & $\begin{array}{l}252 \\
150 \\
400 \\
214 \\
214\end{array}$ & $\begin{array}{l}49 \\
37 \\
80 \\
39\end{array}$ & $\begin{array}{l}26 \\
\frac{11}{15} \cdot 1 \\
15 \cdot 4\end{array}$ & $\begin{array}{r}102 \\
41 \\
57 \\
-\end{array}$ \\
\hline & Mean & 97 & 84 & 18 & 254 & 246 & 51 & $17 \cdot 5$ & 66 \\
\hline \multirow[t]{2}{*}{ B } & $\begin{array}{l}25 \\
26\end{array}$ & $\begin{array}{l}152 \\
172\end{array}$ & $\begin{array}{l}110 \\
115\end{array}$ & $\overline{1}$ & $\begin{array}{l}375 \\
334\end{array}$ & $\begin{array}{l}428 \\
600\end{array}$ & $\begin{array}{l}64 \\
65\end{array}$ & $\begin{array}{l}26 \cdot 5 \\
27 \cdot 0\end{array}$ & $\begin{array}{l}96 \\
82\end{array}$ \\
\hline & Mean & 162 & 113 & 1 & 355 & 514 & 65 & $26 \cdot 8$ & 89 \\
\hline \multirow[t]{2}{*}{ C } & $\begin{array}{l}27 \\
28 \\
29 \\
30 \\
31\end{array}$ & $\begin{array}{l}40 \\
25 \\
39 \\
13 \\
22\end{array}$ & $\begin{array}{l}39 \\
23 \\
37 \\
20 \\
28\end{array}$ & $\begin{array}{r}11 \\
0 \\
23 \\
38 \\
32\end{array}$ & $\begin{array}{r}162 \\
222 \\
88 \\
67 \\
150\end{array}$ & $\begin{array}{l}46 \\
20 \\
20 \\
12 \\
46\end{array}$ & $\begin{array}{l}35 \\
24 \\
30 \\
22 \\
17\end{array}$ & $\begin{array}{r}17 \cdot 3 \\
5 \cdot 7 \\
11 \cdot 2 \\
7 \cdot 4 \\
26 \cdot 0\end{array}$ & $\begin{array}{r}62 \\
21 \\
70 \\
36 \\
140\end{array}$ \\
\hline & Mean & 28 & 29 & 21 & 138 & 29 & 26 & $13 \cdot 5$ & 66 \\
\hline \multirow[t]{2}{*}{ D } & $\begin{array}{l}32 \\
33 \\
\end{array}$ & $\begin{array}{l}96 \\
74 \\
\end{array}$ & $\begin{array}{r}102 \\
71\end{array}$ & $\begin{array}{l}0 \\
3\end{array}$ & $\begin{array}{l}214 \\
220\end{array}$ & $\begin{array}{r}222 \\
80\end{array}$ & 35 & $\begin{array}{l}8 \cdot 5 \\
4 \cdot 0\end{array}$ & $\begin{array}{l}34 \\
14\end{array}$ \\
\hline & Mean & 85 & 87 & $1 \cdot 5$ & 217 & 151 & 35 & $6 \cdot 3$ & 24 \\
\hline
\end{tabular}

months after excision of the bullae. The findings before and after operation are recorded in Table IV (this table also includes the findings in one patient from Group B), the mean values being shown in the right-hand columns. It will be seen that removal of the larger bullae produced little alteration in the lung volumes, mechanical function, or diffusing capacity up to five months after operation. In particular, there was no reduction in the functional residual capacity or residual volume. The largest change was a $13 \%$ increase in M.V.V.80 due to an improvement in the maximum expiratory flow rate. The two patients in whom the bullae occupied more than 


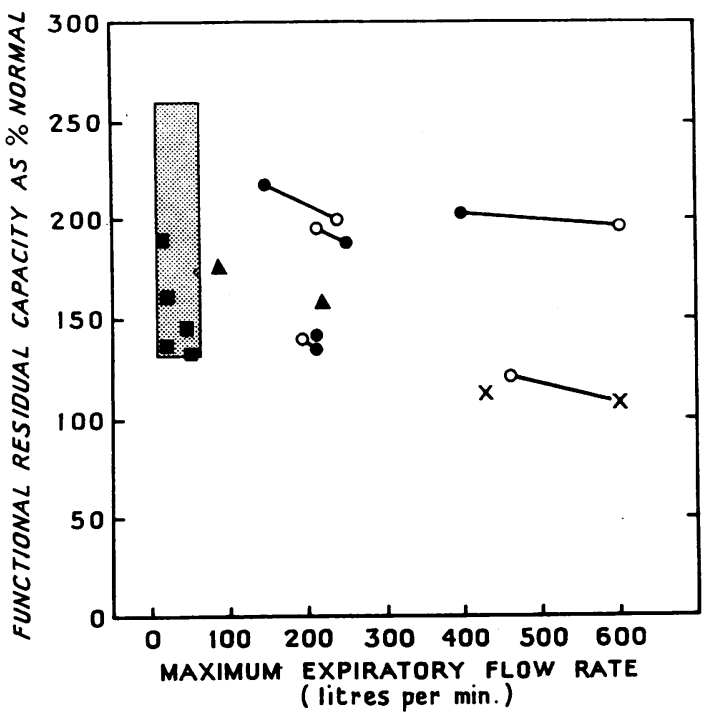

Fig. 1.-Functional residual capacity as percentage of predicted normal plotted against maximum expiratory flow rate in litres min. The stippled area encloses the range of values observed in 19 patients with chronic obstructive vesicular emphysema without radiologically visible bullae (Ogilvie, 1959). Multiple emphysematous bullae: Group A. X Single bulla associated with healthy lungs: Group B. Bullae associated with chronic obstructive vesicular emphysema: Group C. $\Delta$ Honeycomb lung: Group D. O- Post-operative findings.

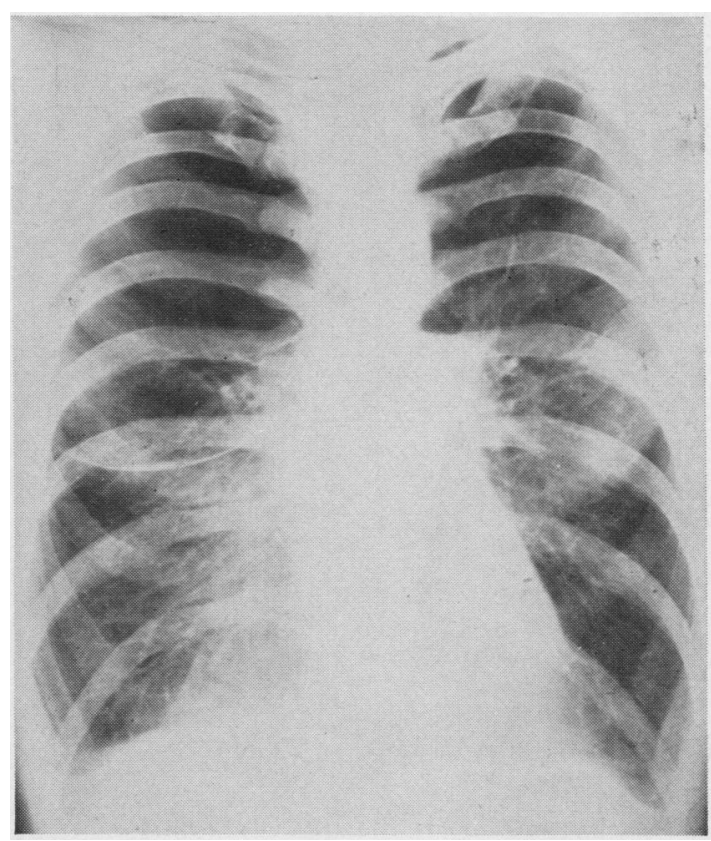

Fig. 2.-Two air cysts at the right upper zone occupying half the hemithorax. Smaller cyst at the left apex (Case 21, Group A).

TABLE IV

PHYSIOLOGICAL FINDINGS IN FOUR PATIENTS WITH BULLOUS EMPHYSEMA BEFORE AND AFTER SURGICAL REMOVAL OF BULLAE

\begin{tabular}{|c|c|c|c|c|c|c|c|c|c|c|c|c|c|}
\hline & \multicolumn{3}{|c|}{ Patient No. 20} & \multicolumn{2}{|c|}{ Patient No. 21} & \multicolumn{2}{|c|}{ Patient No. 22} & \multicolumn{2}{|c|}{ Patient No. 23} & \multicolumn{2}{|c|}{ Patient No. 26} & \multicolumn{2}{|c|}{ Mean Values } \\
\hline & Before & $\begin{array}{l}\text { Two } \\
\text { Weeks } \\
\text { after } \\
\text { Opera- } \\
\text { tion }\end{array}$ & \begin{tabular}{|} 
Five \\
Months \\
after \\
Opera- \\
tion
\end{tabular} & Before & $\begin{array}{l}\text { Two } \\
\text { Weeks } \\
\text { after } \\
\text { Opera- } \\
\text { tion }\end{array}$ & Before & $\begin{array}{c}\text { Four } \\
\text { Months } \\
\text { after } \\
\text { Opera- } \\
\text { tion }\end{array}$ & Before & $\begin{array}{l}\text { Five } \\
\text { Months } \\
\text { after } \\
\text { Opera- } \\
\text { tion }\end{array}$ & Before & \begin{tabular}{|l|} 
Three \\
Months \\
after \\
Opera- \\
tion
\end{tabular} & $\begin{array}{c}\text { Before } \\
\text { Opera- } \\
\text { tion }\end{array}$ & $\begin{array}{l}\text { After } \\
\text { Opera- } \\
\text { tion }\end{array}$ \\
\hline Vital capacity (ml.) .. & 4,470 & 3,750 & 3,950 & 3,515 & 3,245 & 4,000 & 4,500 & 3,625 & 3,530 & 5,125 & 5,000 & 4,147 & 4,045 \\
\hline $\begin{array}{l}\text { Functional residual cap- } \\
\text { acity (ml.) .. } \\
\text { Residual volume (ml.) } \\
\text { Total lung capacity (ml.) } \\
\text { R.V.T.L.C. ratio (\%)... } \\
\text { Maximum voluntary ven- } \\
\text { tilation (M.V.V.80) }\end{array}$ & $\begin{array}{r}4,886 \\
3,140 \\
7,610 \\
41\end{array}$ & $\begin{array}{r}4,355 \\
2,605 \\
6,355 \\
41\end{array}$ & $\begin{array}{r}5,050 \\
3,490 \\
7,440 \\
47\end{array}$ & $\begin{array}{r}6,020 \\
4,325 \\
7,840 \\
55\end{array}$ & $\begin{array}{r}5,065 \\
3,372 \\
6,617 \\
51\end{array}$ & $\begin{array}{r}5,270 \\
3,270 \\
7,270 \\
45\end{array}$ & $\begin{array}{r}5,000 \\
3,500 \\
8,000 \\
44\end{array}$ & $\begin{array}{r}3,305 \\
2,055 \\
5,680 \\
36\end{array}$ & $\begin{array}{r}3,520 \\
2,350 \\
5,880 \\
40\end{array}$ & $\begin{array}{r}2,740 \\
1,315 \\
6,440 \\
20\end{array}$ & $\begin{array}{r}3,310 \\
1,565 \\
6,565 \\
24\end{array}$ & $\begin{array}{r}4,444 \\
2,821 \\
6,968 \\
39\end{array}$ & $\begin{array}{r}4,389 \\
2,855 \\
6,900 \\
41\end{array}$ \\
\hline $\begin{array}{l}(1 . / \min .) \\
\text { Maximum inspiratory }\end{array}$ & 124 & 128 & 139 & 74 & 116 & 128 & 160 & 96 & 100 & 176 & 166 & 120 & 136 \\
\hline $\begin{array}{c}\text { flow rate (l./min.) } \\
\text { Maximum expira ory }\end{array}$ & 252 & 251 & 231 & 214 & 231 & 333 & 332 & 300 & 333 & 334 & 333 & 287 & 292 \\
\hline flow rate (1./min.) & 222 & 273 & 273 & 150 & 240 & 400 & 600 & 214 & 200 & 600 & 462 & 317 & 355 \\
\hline $\mathrm{mm} . \mathrm{Hg} / \mathrm{min})$. & 一 & 一 & - & - & - & 11 & 17 & 15 & 14 & 27 & 26 & 18 & 19 \\
\hline
\end{tabular}

one-half of the hemithorax (Nos. 21 and 22) were responsible for this post-operative improvement in the mean value for M.V.V.80. Patient No. 22 also showed an improvement in diffusing capacity. In these two patients, there was a commensurate improvement in exercise tolerance.

\section{Illustrative CASE}

Patient 22.-This 42-year-old clerk was said to have had pneumonia and pleurisy at the age of 12 .
When he was 35 , a routine miniature radiograph of the chest showed an air-filled cyst or bulla at the right lung apex occupying rather less than one-half of the hemithorax. At this time he was free of symptoms. From the age of 38 , he complained of a slightly productive cough lasting for about two weeks several times each year. $\mathrm{He}$ had noted discomfort in the right side of the chest, and breathlessness on severe exertion (hurrying upstairs or running for a bus) for six months before his first attendance at the London Hospital. 


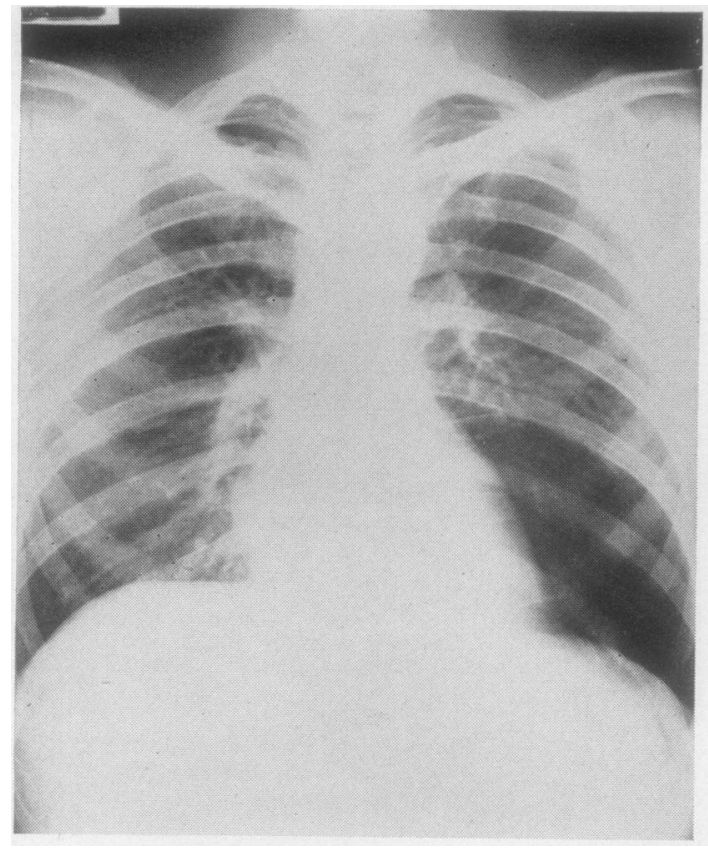

FIG. 3.-Air cyst occupying rather more than the lower third of the left hemithorax (Case 26, Group B).

On examination, there was no cyanosis or clubbing of the fingers. There was a slight fullness of the intercostal spaces below the right clavicle, but the trachea and heart apex were in the normal positions. Chest expansion and breath sounds were diminished and the percussion note increased at the right apex. No adventitious sounds were heard. The chest radiograph showed a large air-filled bulla occupying the upper two-thirds of the right hemithorax.

Resting minute ventilation, vital capacity, M.V.V.80, and maximum flow rates were all within the normal range. The residual volume was increased to more than two and a half times the predicted normal and the ratio of residual volume to total lung capacity was increased. Alveolar mixing efficiency and pulmonary diffusing capacity were moderately impaired.

At thoracotomy, a large emphysematous bulla was found arising from the posterior segment of the right upper lobe. Many smaller bullae, varying in diameter from 0.5 to $3 \mathrm{~cm}$., were found over the pleural surface of the lung especially at the edges of the lobes. The bullae tended to be larger and more numerous over the upper lobe than over the middle and lower lobes. The lower lobe was collapsed by compression. Apical and posterior segmental resections were performed and the patient made an uneventful recovery. Four months later, he stated that he was now able to run for a bus without undue breathlessness. The chest radiograph showed that the remainder of the right lung had expanded to fill the right hemithorax without displacement of the mediastinum. There was a slight improvement in mechanical function and diffusing capacity. Expressed as percentages of original values, the vital capacity had increased by $12 \%$, the M.V.V.80 by $25 \%$ (due entirely to improvement in the maximum expiratory flow rate), and the diffusing capacity by $45 \%$. There was no change in residual volume. which remained at more than two and a half times the normal value, nor in the ratio of residual volume to total lung capacity.

Group B includes two young men in both of whom a large solitary basal bulla, discovered in a routine radiograph (Fig. 3 ), occupied about onethird of the hemithorax, but neither patient complained of any symptoms nor gave a previous history of pneumonia or bronchitis. Physical examination revealed no abnormality other than some increase in percussion note and reduction in breath and voice sounds over the site of the bulla. Values for pulmonary function, including lung volumes, all lay within the normal range. At operation, a single anepithelial air cyst was found arising from the lower lobe in one case and within a sequestrated lobe in the other; the remainder of the lung appeared healthy and free of bullae in both cases. Pulmonary function studies were repeated in patient No. 26 three months after operation and showed no change from the pre-operative findings (Table IV).

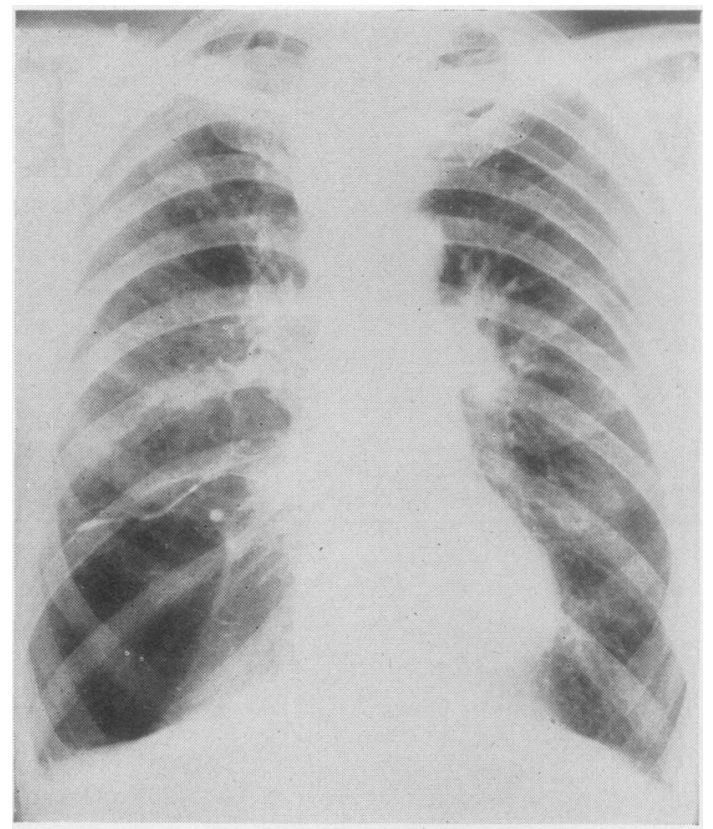

Fig. 4.-Air cyst occupying the lower third of the right hemithorax (Case 27, Group C). 
The five patients in Group $\mathrm{C}$ all gave a history of recurrent attacks of bronchitis and increasing dyspnoea on exertion for an average period of 12 years. One patient had also suffered from asthmatic attacks since early childhood. The degree of disability was severe in four of the five patients and, in two of these, episodes of right heart failure had occurred. One patient subsequently died as a result of a spontaneous pneumothorax, but none of the others gave a history of this condition. The physical signs in each case were those of generalized bronchitis and emphysema. The chest radiographs (Fig. 4) all showed a bulla immediately above the diaphragm (on the right side in three cases and on the left in two) occupying from a third to a half of the hemithorax. The lungs appeared overinflated and both sides of the diaphragm were depressed.

The results of pulmonary function studies were similar to those found in chronic obstructive vesicular emphysema without bullae, the only difference being that the mean increase in residual volume was considerably less (Fig. 1), and the total lung capacity was consequently within normal limits. The mean values for vital capacity, mechanical function, alveolar mixing efficiency, and diffusing capacity were essentially the same in these two groups. In case No. 31 the differential function of the two lungs was studied by bronchospirometry. The left lung, which contained a bulla occupying half the hemithorax, was found to be contributing $39 \%$ of total ventilation, $36 \%$ of total oxygen uptake, and $38 \%$ of the total vital capacity (normal contribution: $45 \%$ ).

Group D consists of two patients, aged 58 and 61 , in whom chest radiographs (Fig. 5) had revealed cystic or "honeycomb" changes diffusely affecting both lungs. Patient No. 32 is described in detail below; the honeycomb changes in this case were attributed to a diffuse interstitial tuberculous pneumonitis. Patient No. 33 had been free of respiratory symptoms until three years previously when he had developed acute bronchitis during the London smog of 1953. Since that time, he had complained of increasing breathlessness on exertion and recurrent attacks of bronchitis with wheezing. On examination, there was moderate cyanosis and clubbing of the fingers. The chest was distended in inspiration and its expansion reduced. Medium crepitations and wheezing rhonchi were audible throughout both lung fields. The chest radiograph showed a diffuse honeycomb appearance in both lungs.

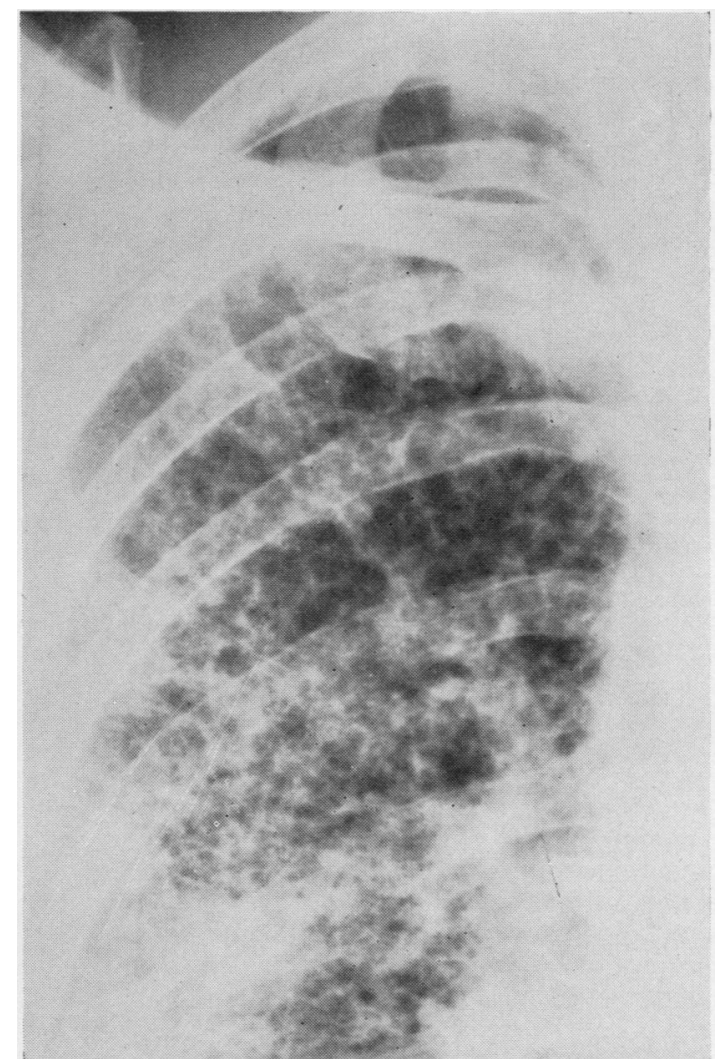

FIG. 5.-View of the right upper zone to show the "honeycomb" appearance (Case 32, Group D).

The most striking abnormality of function in both these patients was the severe impairment of diffusing capacity (mean value $24 \%$ normal) in the presence of relatively good "bellows action" (mean value for M.V.V. $80=87 \%$ normal). This was associated with hyperventilation at rest, the minute volume being raised to between two and three times the normal level, and desaturation of the arterial blood. A second feature of interest was that, as in Group A, there was a considerable increase in residual volume (mean value $214 \%$ normal) and in the R.V./T.L.C. ratio (mean value $49 \%$ ) without significant reduction in vital capacity (mean value $100 \%$ normal) or in the M.V.V.80 (mean value $87 \%$ normal), and unassociated with any evidence of reversible bronchial obstruction.

\section{Illustrative CaSe}

Patient 32.-A 58-year-old cycle builder had noted increasing dyspnoea on exertion for a year and was now breathless even at rest. For six weeks he had 
complained of a cough which was productive of $2 \mathrm{oz}$. $(60 \mathrm{ml}$.) of watery sputum each day; the sputum had been streaked with blood on several occasions. $\mathrm{He}$ had lost 1 stone in weight during the preceding year.

On examination, the patient was breathless at rest and slightly cyanosed. The rate and depth of breathing were increased. There was no finger clubbing and no abnormal signs in the heart, lungs, abdomen, or nervous system. A chest radiograph showed an area of tuberculous infiltration and cavitation at the upper zone of the left lung. The remainder of the lung fields showed a "honeycomb" pattern consisting of multiple air spaces each of about $1 \mathrm{~cm}$. in diameter. This was most marked at the upper and middle zones of the right lung (Fig. 5). The erythrocyte sedimentation rate was $117 \mathrm{~mm}$. in one hour, and the sputum contained tubercle bacilli, both on direct examination and on culture.

The results of pulmonary function studies are shown in Tables II and III. The vital capacity and M.V.V.80 were not reduced, indicating a normal "bellows action," but the residual volume was increased to nearly twice the predicted normal value. The absence of response to bronchodilator drugs suggested that the increased residual volume was not due to expiratory bronchospasm. The most striking abnormality was a reduction in diffusing capacity to about one-third of normal. This was associated with a fall in resting arterial oxygen saturation to $81 \%$ and a considerable degree of hyperventilation, the resting minute volume being increased to three times the normal value.

\section{Discussion}

Group A.-The condition of the five patients in this group corresponds to the descriptions of "bullous emphysema" or "emphysematous blebs" given in the literature (Miller, 1927 ; Price and Teplick, 1946). The clinical picture of "bullous emphysema" has been distinguished from that of "chronic obstructive vesicular emphysema" by Belcher and Siddons (1954). Bullous emphysema tends to develop at an earlier age. It commonly starts in the upper lobes, but both lungs may become diffusely affected. A history of spontaneous pneumothorax was given by nearly half the patients reported by Belcher and Siddons, but this is relatively rare in chronic obstructive vesicular emphysema (Christie, 1952). Conversely, bronchitic symptoms and signs were recorded in less than a quarter of the patients with bullous emphysema but are a common concomitant of chronic obstructive vesicular emphysema (Christie, 1952). The aetiology of bullous emphysema is not known, but the lesions are almost certainly acquired and degenerative (Belcher and Siddons, 1954). Infection has been implicated (Almeyda, 1949), and the history of pneumonia in childhood in three of the five patients in the present study may therefore be relevant.

A pattern of disturbed function characteristic of this group of patients has not previously been described. Ten of the 16 patients with large air cysts or bullae reported by Baldwin and others (1950) had an increased residual volume and were regarded as having emphysema in the remainder of the lungs. Except for a reduced total lung capacity, however, the function pattern was indistinguishable from that found in a group of emphysematous patients without bullae. There was severe impairment of the maximum breathing capacity and evidence of expiratory bronchial obstruction. It has already been noted that most of the patients of Baldwin and others had giant tension cysts which may well have masked the functional state of the compressed lung tissue. In the present study, the patients with bullous emphysema showed an increase in residual volume and functional residual capacity to within the range observed in chronic obstructive vesicular emphysema, yet there was relatively little evidence of expiratory bronchial obstruction (see Fig. 1). This finding suggests that the overinflation of the lung may be due more to inspiratory traction acting upon damaged pulmonary tissue than to generalized obstruction to air flow during expiration. This suggestion is supported by the observation that the functional residual capacity showed no significant fall after removal of the larger bullae, even where there was an improvement in the expiratory flow rate to a high normal value. The persistence of the increase in functional residual capacity to approximately twice predicted normal after operation cannot be attributed to compensatory emphysema in the remainder of the lung since in no case were more than two lung segments excised. These postoperative findings indicate (1) that the individual large bullae were not responsible for the preoperative increase in functional residual capacity, and (2) that they had produced a remediable disturbance in lung function only when occupying more than one-third of the hemithorax. In two patients, the post-operative excess of functional residual capacity and residual volume was the only remaining evidence-clinical, radiological, or physiological - of the widespread bullous changes observed at thoracotomy.

Group B.-The two patients in this group conform to the description by Belcher and Siddons (1954) of " anepithelial" cysts which, they stress, are essentially unassociated with 
generalized emphysema. These cysts occur in young adults. They may reach a great size and produce dyspnoea or pneumothorax, but some remain unchanged in size and cause no symptoms. They have no epithelial lining, are often pedunculated, and the remainder of the lung is healthy.

Pulmonary function studies in these two cases predicted the finding at thoracotomy that the remainder of the lungs was healthy. These studies also confirmed the observation in the previous group that cysts may occupy one-third of the volume of the hemithorax without producing a detectable disturbance in lung function: values for pulmonary function were normal in both patients and, in one, showed no change after the cyst had been excised (see Fig. 1). A lack of significant improvement in the degree of dyspnoea after the removal of cysts occupying less than one-third of the hemithorax has also been recorded by Capel and Belcher (1957).

Group C.-The clinical and physiological findings in these five patients are characteristic of chronic obstructive vesicular emphysema. However, they can be distinguished from emphysematous patients without bullae by the finding of a much smaller increase in residual volume resulting in a normal total lung capacity. This may indicate that the bullae are not freely ventilated and are behaving as "spaceoccupying" lesions. The fact that they encroach more upon the residual volume than upon the vital capacity suggests that they may not in every case exert an unfavourable influence upon lung function. Indeed, it might even be argued that bullae of this size could encourage more efficient ventilation by partial deflation of the overdistended lung. In this connexion, it should be noted that the patient with the largest bulla in this group (Case 31) was the least disabled and that, although the bulla occupied rather more than half the left hemithorax, the lung on this side was still able to contribute about $38 \%$ of the total lung function (normal contribution: $45 \%$ ).

Although the numbers are small, it is of interest that the bullae in these five patients with chronic obstructive vesicular emphysema should all be basal in site while in Group A the large bullae were all in the upper lobes. This difference in the site of the bullae may reflect a difference in pathogenesis. It has been shown that the overinflation of the lung in Group A was unassociated with bronchitis or expiratory bronchial obstruction and it was therefore suggested that the bullae resulted from the effects of inspiratory traction upon abnormal lung tissue. This would explain the greater incidence of bullae in the upper iobe and over the free margins of the lung. Conversely, the bronchitis and expiratory bronchial obstruction observed in Group C would have a greater impact in the dependent parts of the lung where there is a greater tendency for the increased bronchial secretions to be retained. In this group, airway obstruction during expiration may thus play the more important part in the formation of large bullae.

Group D.-The chest radiographs of the two patients in this group showed honeycomb changes diffusely affecting both lungs but no giant bullae. In one patient, the honeycomb changes were associated with a diffuse interstitial tuberculous pneumonia and, in the other, symptoms dated from an acute respiratory infection during the London smog. In a description of the pathology of honeycomb lung, Heppleston (1956) referred to three patients in whom the condition was associated with tuberculous bronchopneumonia and four patients in whom no specific cause was found but whose symptoms had first appeared after an acute respiratory infection. Heppleston found that interstitial lung fibrosis or granulomata are the usual antecedents of honeycomb lung, the cystic spaces being derived from the excessive inspiratory dilatation of bronchioles adjacent to the fibrosed areas. Valvular bronchiolar obstruction may develop as the cysts increase in size and act as a secondary factor in the production of the larger cysts.

The finding in these two cases of a severe impairment of diffusion associated with hyperventilation, desaturation of the arterial blood, and relatively normal mechanical function is characteristic of the "alveolo-capillary block" syndrome (Baldwin, Cournand, and Richards, 1949 ; Austrian, McClement, Renzetti, Donald, Riley, and Cournand, 1951). This syndrome has been described in association with diffuse interstitial fibrosis and granulomata, and its occurrence in the present group is therefore in keeping with Heppleston's histological observations in honeycomb lungs. In previous accounts of the functional disturbance in diffuse interstitial fibrosis, the condition was not complicated by honeycomb or cystic changes in the lung, and the residual volume was found to be normal or decreased (Baldwin and others, 1949). In the present study, the residual volume and functional residual capacity were significantly increased and were in fact greater than in 20 patients, studied in the same laboratory, in whom there was a diffuse 
interstitial fibrosis without honeycomb changes. The finding of an increased residual volume with relatively little expiratory bronchial obstruction nor any evidence of bronchospasm (no response to bronchodilator drugs) suggests that, as in Group $A$, the overinflation of the lung may be due more to inspiratory traction (" compensatory emphysema") than to expiratory obstruction. This observation is again in keeping with Heppleston's conclusions regarding the pathogenesis of honeycomb lung.

\section{SUMMARY}

The lung volumes, the mechanical and ventilatory function of the lungs, and the pulmonary diffusing capacity were measured in 14 patients with pulmonary bullae. These patients were divided into four groups according to the clinical, radiological, and surgical findings, and the patterns of dysfunction were compared with those observed in chronic obstructive vesicular emphysema.

Group A. Multiple Emphysematous Bullae. -The clinical features of this group included a tendency to spontaneous pneumothoraces, minimal evidence of bronchitis, and only slight disability which was not progressive. The bullae were largest in the upper lobes. The functional disturbance was distinguished from chronic obstructive vesicular emphysema by the finding of an increased residual volume (unaffected by excision of the larger bullae) in the presence of a relatively normal maximum expiratory flow rate. This suggests that inspiratory traction upon damaged lung tissue rather than expiratory bronchial obstruction was responsible for the overdistension of the lung.

Group B. Solitary Bullae with Healthy LuNGS.-Although the bullae occupied one-third of the hemithorax, the patients in this group were free of symptoms and tests of pulmonary function were entirely normal.

Pulmonary function studies were repeated in five patients from Groups $A$ and $B$ after removal of the larger bullae. There was a slight improvement in function when the bulla had occupied one-half or more of the hemithorax, and no improvement when the bulla had occupied onethird of the hemithorax.

Group C. Bullae Associated with Chronic Obstructive Vesicular Emphysema. - The patients in this group gave a long history of recurrent bronchitis associated with moderate to severe disability. The bullae were all situated in the lower lobes. The clinical and physiological picture was identical to that observed in patients with chronic obstructive vesicular emphysema without bullae except that the increase in residual volume was considerably less. It was suggested that in this group the bullae may not exert an unfavourable influence on pulmonary function when they encroach more upon the residual volume than upon the vital capacity.

Group D. "Honeycomb LUNGS."-The two patients in this group gave a relatively short history of rapidly progressive dyspnoea culminating in severe disability. The chest radiographs showed "honeycomb" changes diffusely affecting both lungs; there were no giant bullae. In one case, the changes were attributed to a diffuse interstitial tuberculous pneumonitis. As in Group A, there was an increased residual volume without commensurate expiratory bronchial obstruction. There was in addition a severe degree of alveolo-capillary block. These findings are in keeping with the known pathogenesis of honeycomb lung.

In conclusion it may be said that the functional disturbance in patients with pulmonary bullae is determined more by the state of the lungs as a whole than by the effect of an individual bulla which occupies less than half of one hemithorax.

I wish to express my gratitude to Dr. Kenneth Perry, Dr. Lloyd Rusby, and Professor Clifford Wilson for their constant interest and helpful advice during the preparation of this paper. I am also grateful to Mr. Vernon Thompson and Mr. Geoffrey Flavell for allowing me to study patients under their care.

\section{REFERENCES}

Almeyda, J. (1949). Brit. J. Tuberc., 43, 74.

Austrian, R., McClement, J. M., Renzetti, A. D., Jr., Donald, K. W., Riley, R. L., and Cournand, A. (1951). Amer. J. Med., 11, 667. Baldwin, E. deF., Cournand, A., and Richards, D. W., Jr. (1949). Medicine (Baltimore), 28, 1.

Harden, K. A., Greene, D. G., Cournand, A., and Richards, D. W. (1950). Ibid., 29, 169.

Belcher, J. R., and Siddons, A. H. M. (1954). Thorax, 9, 38.

Capel, L. H., and Belcher, J. R. (1957). Lancet, 1, 759.

Christie, R. V. (1952). In Diseases of the Chest, Vol. 2, p. 101, edited by Marshall, G., and Perry, K. M. A. Butterworths, London.

Heppleston, A. G. (1956). Thorax, 11, 77.

Miller, W. S. (1927). Amer. J. Roentgenol., 18, 42.

Ogilvie, C. M. (1959). Thorax, 14, 113.

Price, A. H., and Teplick, G. (1946). Arch. intern. Med., 77, 132. 